\title{
The Employment of the Stream of Consciousness in Munro's Amundsen
}

\author{
Yuan-zhen PENG \\ North China Electric Power University, English Department, Baoding City, Hebei, \\ People's Republic of China \\ ohamster@126.com
}

Keywords: Narrative style, Stream of consciousness, Love.

\begin{abstract}
The story Amundsen adopts the perspective of the first-person narrator all through, telling the narrator's own experience in Amundsen and her own feelings and thoughts. Two separate worlds were unfolded: one was what was happening in the outside world; the other was what was crossing the narrator's mind after falling in love.
\end{abstract}

\section{Introduction}

The story Amundsen is the second short story in the collection Dear Life, which is narrated by the first person narrator who went to work as a teacher at the San. There was no pressure for competitiveness was discouraged. Everybody was afraid of getting a cold. The narrator, working on her MA, attempted to make some changed in her class, but the doctor named Alister broke up her class. She was frustrated and fled to Amundsen where she thought she could be invisible but in fact she met Mary and she even fell in love with the doctor who lived in Amundsen. Like the story To Reach Japan, the first one in the same book Dear Life, romantic love is still the theme of Amundsen. The plot is clear and simple. The doctor invited the narrator to dinner in his own house and then even intended to get married. But ultimately the doctor gave up the idea of marriage and drove the narrator to the train station to go back to Toronto. The narrator got married later in Toronto and came across the doctor on a crowded street. Besides the plot of the story, the narrator's own feelings, imaginations and thoughts were exposed. Techniques of stream of consciousness being used, we get to learn what love means to the female narrator and to the male doctor. In terms of reaction to romantic love, females and males are different species.

\section{Parallel Lines: Reality and Love}

The title is the name of the place the love story happened, Amundsen, which carries the narrator's memory of love. It is an experience so clear to the narrator herself that the present tense is employed when she recalled the school's then situation and their plan to get married, in Section Three, Thirteen and Fourteen respectively. The narrator is the main character. The whole story is told from her own perspective, about what she saw, how she felt about the scenery, the school, the men and the women, and especially about the doctor. The story was not as romantic as usual. There were neither flowers nor dates. The characters who fell in love were a teacher and a doctor. The teacher came to teach in the woods. She felt frustrated after one day the doctor rudely and unexpectedly broke up her class. She came to Amundsen for relief and escape from gossips. The story is written logically according to the time sequence before she went to the doctor's house for dinner. Since the seventh section, the doctor jumped onto the scene and played a 
major role in the narrator's life. They even planned to get married with each other. How the narrator felt about the love between them is exposed by letting the narrator face her mind and express herself. After years of separation, when they saw each other, the narrator could still feel the love in her mind, just as the ending said, "Nothing changes really about love." The doctor remained the same as well. Whenever seeing the narrator's strong passion for him, he appeared to be lost and frightful. He was afraid of staying together with the narrator for a while after they had a relationship. Before that, he was active in inviting the narrator to his house, in talking with her and in building an intimate relationship between them. He even humiliated Mary in front of the narrator. All this made a deep impression on the narrator and she could not help falling in love with the doctor. Fortunately, the narrator was sensible enough to regain herself by following the doctor's advice getting on the train for Toronto, although she cherished the then love all the time. The ending fits into Munro's original design as she began writing. She (Isberg, 2014) said in a video interview that she wanted to change the sad ending of Andersen's Mermaid by writing herself.

The narrator arrived in a white wooden building in the woods by taking a car with a group of men who got off when it stopped at a sawmill. She was amazed at the natural scenery, silent and austere, although cold. She was lost in the stillness. When she met Dr. Fox for the first time, she was wise enough to figure out his traps lying behind the questions he posed. Given his questions and his remarks, he was not a man without wit. The tone in the first section is light and humorous. There are some sentences that are really funny. "Then somebody remembered that it was the missing man's day off."(Munro, 2012, p.32) "I considered the ethics of stealing from a thief." (Munro, 2013, p.34) When the narrator proudly told Mary she was the teacher from Toronto, Mary's reaction also provokes the outbreak of laughter. "There was a certain pause, perhaps of respect. But no. An examination of my coat." (Munro, 2012, p.34) After the narrator told Mary her family name, Mary immediately responded in such an amusing manner. "'Tan your hide,' she said. 'Sorry, I just thought that up." The narrator must be in a mood to laugh although they had negative literal meaning. Plus, Reddy Fox, a spare man, did not possess less wit than the narrator or Mary. The conversation between him and the narrator is also undoubtedly funny enough. When talking about working together with them in their woods, the narrator compared the situation to living inside a Russian novel and to the novel War and Peace that was the only one she could recall. Mr. Fox's reaction was interesting enough to entertain the reader. "Well, it's only the Peace we've got here, I'd say. But if it was the War you were hankering after I suppose you would have joined one of those women's outfits and got yourself overseas." (Munro, 2013, p.36) In short, the first section creates a delightful atmosphere in the silent, cold and fascinating woods. In the narrator's eyes, the place where she was going to work as a teacher was beautiful and full of charming stillness. "Then there was silence, the air like ice. Brittle-looking birch trees with black marks on their white bark, and some kind of small untidy evergreens rolled up like sleepy bears. The frozen lake not level but mounded along the shore, as if the waves had turned to ice in the act of falling. And the building beyond with its deliberate rows of windows, and its glassed-in porches at either end . Everything austere and northerly, black-and-white under the high dome of clouds. .... So still, so immense an enchantment." (Munro, 2012, p.32-33)

Section Two gives a brief introduction about the values and interests of Matron and three nurses. Matron was good at dealing with complaints, inquiries and arrangements. The three nurses were not the least enthusiastic about life they did not know, including Toronto, the big and famous place the narrator came from, and the narrator's job as a 
teacher, let alone such issues as culture. They could be described as "narrow" and only concerned with marriages or engagements. As to their attitudes toward Dr. Fox, the word "awe" was employed, for Dr. Fox read many books and tore a strip off them when he wanted to.

Section Three is short and unique for it is the only one written in the italic form. The part is apparently giving comments on the teaching and learning in the school in the woods. It can be a diary by the narrator herself. Present tense is put into use so it is written at that time. From her opinions, it seems that children are not eager to acquire knowledge to pass examinations and teachers are cautious at bring out overexcitement or imposing so much pressure on them. Everything was meant to make the school be rather a pretend one than a real one. "Usual notions of pedagogy out of place here. Some of these children will reenter the world or system and some will not. Better not a lot of stress. That is testing memorizing classifying nonsense. Disregard whole grade business entirely. Those who need to can catch up later on or do without. Actually very simple skills, set of facts, etc., necessary for Going into the World. What about Superior Children so-called? Disgusting term. If they are smart in questionable academic way they can easily catch up. Forget rivers of South America, likewise Magna Carta. Drawing Music Stories preferred. Games Okay but watch for overexcitement or too much competitiveness. Challenge to keep between stress and boredom. Boredom curse of hospitalization." (Munro, 2012, p.39) This special section shows that the narrator was devoted to her job as a teacher. She was concerned about the teaching and learning in the school. The narrator loved her job and proved to be qualified for it, which unexpectedly disturbed the doctor who disturbed the narrator in reverse. In the fourth section, the narrator made a commotion for trying to inspire the children to learn more in a more eager manner. The doctor came into the classroom once and destroyed the excitement in class. Although the narrator attempted to justify herself in converting the class into a real one, nobody was sympathetic with her. She felt like a total fool in the no more interesting place. As a result, the scenery and people were not as beautiful as the first day she came here. Everything she did - for example, she looked at the lake or she came to teach in the woods - seemed strange and abnormal. This is the fifth section. The narrator did not feel at ease any more in the school. She was out of place, in one word. In Section Six, the narrator went to Amundsen to relax herself because it was believed that nobody knew her. To her surprise, she was confronted with Mary who led her back along a short cut. In Amundsen the narrator paid her attention to the doctor's house and made a speculation that he had no wife and he had many books.

From Section Seven the story jumped to the narrator's meeting with the doctor at his house. It is typically the stream of consciousness, with no regard to physical time and space and no explanation of how they got to stay together. The narrator remembered everything clearly about the dinner: how the doctor prepared the dishes, how he tried to heat the rooms and the names of the books he had. She even used direct speech when recalling the dialogue between them. The doctor did not want to talk about books with the narrator, but asked whether she had a boyfriend and easily discovered that she told lies. He skillfully avoided the awkwardness and continued the conversation smoothly by honestly answering the narrator's questions about him. What made the narrator unforgettable was the weight the doctor imposed on her back with his fingers. "When the ends were efficiently tied he laid his hand against my upper back. Such firm pressure, fingers separated - he might almost have been taking stock of my body in a professional way. When I went to bed that night I could still feel that pressure. I felt it develop its intensity from the little finger to the hard thumb. I enjoyed it." (Munro, 2012, p. 51) 
Questions about whether she had a boyfriend and body contacts were useful enough to ignite a woman's imagination about love or about being loved. That's to say, the doctor knew how to motivate a woman's passion. Without being refused, the doctor asked for a second time to have dinner together at his house again. The narrator also remembered all the details very clearly. At last, they experienced what both of them longed for. The narrator's imagination functioned as well as the doctor's experience. During the process, the doctor told the narrator that he did intend to marry her. After that, they went in opposite directions in terms of reactions to their romantic relationship. It seemed that love reached its climax and then went down from the doctor's perspective and love started to go up from the narrator's perspective. One began to escape and the other began to be ready for more happiness. Men and women seemed to live in two separate planets.

In the thirteenth and fourteenth sections, present tense is employed. The narrator went back to her memory again because they were going to get married at that time. She was such a happy lady. She imagined the wedding ceremony and different ways to get married. Section Thirteen begins as follows. "We are going to Huntsville. Going to Huntsville - our code for getting married." (Munro, 2012, p.58) The narrator was evidently in a light mood. She would really like to get married with the doctor. Everything could continue as planned. Strangely, after talking with some other man and agreeing to park his car elsewhere, the doctor changed his mind. He shrank and apologized by saying it was a mistake to fall in love. Then the doctor felt relieved. The narrator was awful. "It's something like being driven to the place of execution."(Munro, 2012, p.62) I was so angry that I suspected him of dating other girls and breaking up with them by the same method. The narrator did not insist staying but all the time she was expecting that the doctor would come back to be with her. To her disappointment, he never came back. She remembered his eyes and one of them was wide open. "And it always looked so strange, alert and wondering, as if some whole impossibility had occurred to him, one that almost made him laugh." (Munro, 2012, p. 66) From the description and evaluation, it can be seen that the narrator was still inclined to believe that the doctor loved her. A touch of warmth spreads over our whole body. The innocent belief is the light of the sun.

\section{Conclusions}

Munro's Amundsen is no doubt an interesting story with a touch of pain attributed to love beyond reach yet hidden in the deep consciousness of the female narrator. She experienced frustration due to her odd attitudes toward work in the woods where women were expected to have men and were not so concerned about their jobs. She experienced the excitement and happiness of being loved by a man and also the sadness and disappointment of being discouraged to keep in love with the man. It was fortunate that the female narrator did not totally get lost for the sake of love. She had her own life, husband and marriage, although not perfect but real. Love is an experience that cannot be taught. Love can be a sweet memory if being cherished. Love should not be a cage to be used by men to imprison women or to be used by women to imprison men. Females and males have different attitudes toward love. When females are not valued any more by males, they have to learn to be the owners of their consciousness. Only in this way can they be the master of their own emotional lives, which may be supposed to the real purpose of Munro's writing. Munro shows her deep and great compassion toward women's fate and life. 


\section{Acknowledgements}

This work was financially supported by the Fundamental Research Funds for Central Universities (2014MS175).

\section{References}

[1] Alice Munro, Dear Life, Vintage Books, New York, 2012.

[2] Alice Munro, Jeanne McCulloch, and Mona Simpson, The Art of the Novel: An Interview with Alice Munro, trans, Yang Zhentong, Contemporary Writers Review, Vol.4, pp. 185-202, 2014.

[3] Hongyu Liu, Dear Life: A Lacanian Psychological Illustration, Foreign Literature Studies, Vol.2, pp.158-162, 2015.

[4] Jacques Lacan, Ecrits: the First Complete Edition in English, trans. by Bruce Fink, W. W. Norton \& Company, Inc. New York, 2006.

[5] Stephen Isberg, Alice Munro: Live in Her Own Words, trans. by Li Wenjun, World Literature, Vol.2, pp. 67-79, 2014.

[6] Weiping Li \& Xiaoming Chen, Foreign Language Academic Popularization Series: What is a Stream of Consciousness Novel, Shanghai Foreign Language Education Press, Shanghai, 2012. 